випр.]. - Рівне : Волинські обереги, 2011. - 522 с. 7. Кизенко В. І. Система підготовки вчителя до проведення факультативних занять / В. Кизенко // Біологія і хімія в сучасній школі. - 2012. - № 5. - С. 23 - 28. 8. Сучасний урок. Інтерактивні технології навчання : [наук.-метод. посібн.] / О. І. Пометун, Л. В. Пироженко; за ред. О. І. Пометун. - К. : Видавництво А.С.К., 2004 - 192 с. 9. Хуторской А. В. Современные педагогические инновации на уроке / А. В. Хуторской // Интернетжурнал «Эйдос» [Електронний ресурс]. - 2007.- 5 июля.- режим доступу : http://www.eidos.ru/journal/2007/0705-4.htm. 10. Чепіль М. М. Педагогічні технології : навч. посіб. / М. М. Чепіль, Н. 3. Дунник. - К. : Академвидав, 2012. $224 \mathrm{c}$.

УДК 371.3:811.161.2

Вікторія Зінченко

\title{
РОБОЧИЙ ЗОШИТ ЯК ЗАСІБ ФОРМУВАННЯ МОВНО-МОВЛЕННСВОЇ КОМПЕТЕНТНОСТІ СТАРШОКЛАСНИКІВ
}

Зінченко В. М. Концептуальні засади формування мовно-мовленнєвих компетентностей учнів старших класів профільної школи.

У статті визначено мету й завдання профільного курсу української мови, сформульовано концептуальні засади вдосконалення змісту й організації навчання української мови учнів старших класів профільної школи на основі системного підходу та запропоновано концепцію навчання української мови у профільних класах загальноосвітніх навчальних закладів (профіль - українська філологія).

Ключові слова: концептуальні засади, профільний курс української мови, мовно-мовленнєві компетентності, концепція навчання.

Зинченко В. М. Концептуальные основы формирования языково-речевых компетентностей учеников старших классов профильной школы.

В статье определены цели и задачи профильного курса украинского языка, сформулированы концептуальные основы усовершенствования содержания и организации обучения украинскому языку учеников старших классов профильной школы на основе системного подхода и предложена концепция обучения украинскому языку в профильных классах общеобразовательных учебных заведений (профиль - украинская филология).

Ключевые слова: концептуальные основы, профильный курс украинского языка, языково-речевые компетентности, концепция обучения.

Zinchenko V. M. Conceptual basics of the language and speech competences formation of the students from specialized high school.

The article determines objectives and problems of the Ukrainian specialization course, defines conceptual basis of the improvement of Ukrainian specialized high school educational contents and organization on the systems approach ground; suggests the language teaching conception of Ukrainian in the specialized high school classes (specialization - Ukrainian philology).

Key words: conceptual basis, Ukrainian language specialized course, language and speech competence, educational conception. 
Зміст навчання української мови у профільній школі - це формування мовної, лінгвістичної, мовленнєвої, комунікативної, риторичної компетенцій учнів, а також розвиток професійно зорієнтованого мовлення.

Аналіз науково-методичних досліджень [1; 2; 4; 6] і практичного досвіду спонукає до пошуків нових підходів до формування мовно-мовленнєвих компетентностей учнів філологічних класів i до впровадження новаторських здобутків у процес профільного навчання української мови.

Метою статті є запропонувати концепцію навчання української мови в профільних класах загальноосвітніх навчальних закладів (профіль- українська філологія). Відповідно до мети сформульовані завдання дослідження: визначити основну мету й завдання профільного курсу української мови; сформулювати концептуальні засади вдосконалення змісту й організації навчання української мови учнів старших класів профільної школи на засадах системного підходу.

Профільний курс української мови має на меті удосконалення набутих в основній школі мовно-мовленнєвих умінь і навичок; формування уміння грамотно, чітко й повно викладати думки щодо майбутньої професійної діяльності; формування вмінь і навичок комунікативно виправданого використання засобів мови; удосконалення правописної компетенції майбутніх філологів; поглиблення професійно значущого контексту знань з української мови; засвоєння знань про особливості стилів української мови відповідно до вимог культури усного й писемного мовлення, основ практичної риторики.

Задля досягнення високого рівня мовно-мовленнєвих компетентностей учнів (як у соціальному, так і в професійному контексті) слід передбачити розв'язання таких завдань у процесі вивчення профільного курсу української мови: здійснення необхідної мовної підготовки учнів філологічного профілю відповідно до вимог майбутньої професії; формування комунікативних умінь у різних видах мовленнєвої діяльності; поглиблення лінгвістичних знань; розширення загальноосвітнього кругозору, розвиток загальної та комунікативної культури.

Запропонована для формування мовно-мовленнєвих компетентностей учнів профільних філологічних класів концепція передбачає вдосконалення змісту навчання професійно зорієнтованого мовлення, що охоплює мовний матеріал, правила його оформлення і навички його вживання; мовленнєві дії та мовленнєвий матеріал (мовленнєві зразки, тексти); комплекс мовленнєвих умінь, що характеризують рівень практичного володіння сучасною літературною українською мовою як засобом спілкування в різноманітних ситуаціях.

Готовність до продовження філологічної освіти у виші й до майбутньої професійної діяльності передбачає повну реалізацію мети та завдань профільного курсу української мови, що, у свою чергу, зумовлює необхідність розроблення навчально-методичної системи формування мовно-мовленнєвих компетентостей учнів профільних філологічних класів.

В основу пропонованої навчально-методичної системи покладено такі підходи у профільному навчанні української мови: особистісно зорієнтований (І. Бех, Л. Мацько, С. Рубінштейн, О. Савченко, А. Хуторський, І. Якиманська); системний (О. Горошкіна, С. Караман, Л. Мацько, М. Пентилюк, К. Плиско); компетентнісний (Н. Бібік, О. Овчарук, М. Пентилюк, О. Пометун, О. Савченко, С. Трубачова); суб'єктно-діяльнісний (Л. Занков, О. Любашенко, Н. Хомський, А. Хуторський); комунікативно-діяльнісний (Ф. Бацевич, О. Біляєв, Н. Голуб, Т. Донченко,

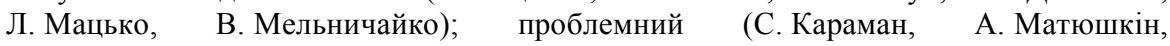
Т. Симоненко, Л. Скуратівський, М. Степаненко). 
Перед профільною освітою нині стоїть важливе завдання - розвиток особистості учня, виховання людини, здатної адекватно відповісти на виклики сучасності й реалізувати себе у професійній діяльності. Особистісно зорієнтований підхід грунтується на виявленні індивідуальних особливостей учня й забезпечує розвиток особистості, тому у пропонованій нами навчально-методичній системі чільне місце відведено особистісно зорієнтованому та суб'єктно-діяльнісному навчанню.

Компетентнісний підхід передбачає набуття учнями важливих предметних, загальнокультурних, соціальних, галузевих компетентностей.

Задля реалізації системного підходу у процесі навчання профільного курсу української мови (профіль - українська філологія) нами запропоновано поетапне формування мовно-мовленнєвих компетентностей учнів за такою схемою: наукове поняття - положення теорії - наслідки - формування зазначених компетенцій застосування компетенцій у практичній діяльності.

Для наочного уявлення про абстрактні поняття мовної системи, взаємозв'язки

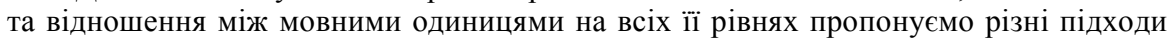
до моделювання кожного розділу або теми.

Теоретичний матеріал слід подати у вигляді узагальнювальних схем, таблиць, моделей, які демонструються на інтерактивній дошці, що сприятиме свідомому вивченню мовних понять і правил. Урахування основних умов системного підходу в навчанні передбачає: блокове компонування теоретичного матеріалу укрупненими частинами та максимальну конкретизацію абстрактних правил i понять за допомогою прикладів. Це покликане забезпечити системний виклад, чітке відображення основних положень, ідей, створення цілісної картини 3 окремих понять, правил, тем, запам'ятовування логічних зв'язків і визначень [4].

За умови блокового компонування матеріалу в узагальнювальних таблицях, схемах і моделях його можна багаторазово повторювати: під час створення таблиці або схеми, зображення іiі на дошці, у процесі аналізу й під час перенесення до конспектів, зіставлення таблиці - схеми - моделі з матеріалом підручника, під час виконання вправ і завдань.

Блокове компонування теоретичного матеріалу допомагає учням сприймати систему мови, іiі структурні компоненти цілісно, з виокремленням рівнів мовної системи, її підсистем, мовних одиниць, засобів і відношень між елементами мови, тобто подолати подрібнення навчального матеріалу [5].

Вивчення мови як засобу спілкування, що здійснюється у процесі чотирьох видів мовленнєвої діяльності - аудіювання, читання, говоріння, письма, передбачає комунікативно-діяльнісний підхід (когнітивно-комунікативний), за якого формування мовних знань і умінь підпорядковане розвитку мовлення й потребує впровадження інноваційних технологій та оптимального поєднання різних форм організації навчального процесу [2].

Відповідно до розробленої системи всі види мовленнєвої діяльності реалізовуються шляхом виконання різних вправ i завдань комунікативного спрямування, що значною мірою підвищує культуру мовлення учнів. Відбувається поетапне формування мовної, мовленнєвої, комунікативної, лінгвістичної компетенцій шляхом опрацювання теорії, виконання системи вправ і завдань, продукування текстів різного, зокрема й професійного спрямування. Інтенсивна мовленнєва практика сприяє збагаченню лексичного запасу учнів, озброює їх теоретичними знаннями, допомагає їм підвищувати культуру власного мовлення. 
На думку М. Вятютнєва, Реалізація комунікативно-діяльнісного підходу дає можливість учням профільних філологічних класів усвідомити мову як форму вираження національної культури, менталітету, закономірностей, структури та системної організації мови загалом [2].

Українські лінгводидакти О. Біляєв, Т. Донченко, С. Караман, Л. Мацько, М. Пентилюк, I. Хом'як вважають, що технологія навчання мови грунтується на проблемному підході. Ми розглядаємо проблемне навчання як спосіб керування пізнавальною діяльністю учнів; як психолого-педагогічну систему форм, методів і засобів розвивального навчання, що сприяє активному оволодінню ними новими знаннями, навичками й способом дій; як частину цілісної системи навчання 3 інноваційною структурою підходів до виконання вправ і розв'язання завдань.

Основну увагу під час профільного вивчення української мови (профіль українська філологія) у пропонованій навчально-методичній системі приділено потребам учнів з урахуванням їхнього досвіду та рівня розвитку, приділено не тільки знанням, а й розвитку особистості через здобуті знання [2]. Тобто, результатом навчальної діяльності має бути не розв'язання конкретного завдання, а оволодіння комплексом компетенцій (мовних, мовленнєвих, комунікативних).

У розробленні концептуальних засад до вдосконалення змісту й організації навчання української мови учнів старших класів профільної школи на засадах системного підходу визначено такі основні компоненти: 1) створення робочого зошита для роботи учнів на уроках та в позаурочний час; 2) блокове компонування навчального матеріалу; 3) вибір ефективних технологій навчання. Кожен із компонентів спроектовано з урахуванням загальнодидактичних, лінгводидактичних та власне методичних принципів і підходів, засад гуманізації освіти, розвитку особистості, комплексу компетенцій (мовних, мовленнєвих, комунікативних).

Для формування готовності учнів профільних філологічних класів до подальшого навчання, майбутньої професійної діяльності розроблено робочі зошити для профільного вивчення української мови в X і XI класах, де передбачено поетапне формування мовно-мовленнєвих компетентностей, підвищення рівня культури мови й мовлення.

Учням $\mathrm{X}$ класу запропоновано робочий зошит у доповнення до підручника 3 української мови профільного рівня, структурований за рубриками: «Знову про морфологію», «Цікаво про мову й мовознавство», «Лабораторія дослідника», «Юному філологу», «Практикум з орфографії», «Практикум з розвитку мовлення».

Для учнів XI класу розроблено робочий зошит у доповнення до підручника 3 української мови профільного рівня, структурований за рубриками «Знову про синтаксис», «Цікаво про мову й мовознавство», «Лабораторія дослідника», «Юному філологу», «Практикум з пунктуації», «Практикум з розвитку мовлення».

Мета розроблених робочих зошитів - формування в учнів старших класів профільної школи (профіль - українська філологія) конкретних мовних, мовленнєвих і комунікативних компетенцій, поглиблення знань 3 мови, з культури усного й писемного мовлення.

На першому етапі роботи з робочим зошитом під час вивчення профільного курсу української мови в X класі основну увагу зосереджено на формуванні мовних, мовленнєвих, комунікативних компетенцій (мотиваційно-пізнавальний етап), необхідних для правильного користування багатством мови; на закріпленні набутих в основній школі знань 3 морфології, удосконаленні орфографічних, граматичних, лексичних умінь; оволодінні навичками перекладу з російської на українську мову й навпаки, професійною лексикою майбутнього фаху. 
На другому етапі у процесі вивчення профільного курсу української мови в XI класі робочим зошитом передбачено закріплення набутих в основній школі знань із синтаксису, вдосконалення пунктуаційних умінь; формування мовномовленнєвих умінь (створення усних висловлювань), що потребує зосередження уваги на осмисленні логіки викладу, виділенні головного й другорядного; оперування різними прийомами фіксації почутого (запис ключових слів, план висловлювання, аналіз тексту, дискусії тощо); створення письмових текстів різних стилів і типів мовлення з урахуванням точності, доречності, логічності, багатства мовлення; інтонування власного мовлення для більш точного відтворення змісту сказаного. На другому етапі створюються умови задля закріплення й розвитку мовних, мовленнєвих, комунікативних компетенцій учнів.

У кожному класі профільної школи передбачено поетапне формування й удосконалення мовно-мовленнєвих компетентностей iз виокремленням функціональних ліній етапу, мети, системи вправ.

Особливу увагу в пропонованому підході до вдосконалення змісту й організації навчання української мови учнів філологічних класів у профільній школі приділено змістовим аспектам робочого зошита в доповнення до змісту підручників «Українська мова (профільний рівень)» для Х і XI класів.

Зміст робочого зошита укладено відповідно до вимог Національної доктрини розвитку освіти України у XXI столітті, Законів України «Про освіту», про мови, Концепції мовної освіти в Україні, Державного стандарту мовної освіти, Державної національної програми «Освіта» (Україна XXI століття), Загальноєвропейських Рекомендацій з мовної освіти [3], Концепції профільного навчання в старшій школі, Концепції профільного навчання української мови в старшій школі; ураховано державний статус української мови, її суспільні функції, узято до уваги специфіку профільного курсу української мови, а також визначено стратегічні напрями (змістові лінії: соціокультурна, мовна, мовленнєво-діяльнісна, комунікативнодіяльнісна).

Соціокультурна змістова лінія передбачає наявність в учнів знань країнознавчого та лінгвокраїнознавчого характеру: знання історії, літератури, культури України, регіону. Оволодіння мовою неможливе без вивчення культури країни. Тому важливим $є$ використання текстів соціокультурного спрямування у процесі формування мовно-мовленнєвих компетентностей. До того ж, зміст текстів $€$ зразком для учнів під час створення власних висловлювань.

Навчання української мови на профільному рівні має забезпечити єдність навчання, виховання та цілеспрямованого інтелектуального розвитку особистості, культури мови, що перебуває в діалектичному зв'язку з культурою мовлення, а також передбачає створення умов для самореалізації й саморозвитку [4, с. 12-16].

Соціокультурний аспект сприяє формуванню загальної культури учнів філологічних класів профільної школи; розумінню прекрасного в мові, що спирається на іiі лексичні, фразеологічні, граматичні ресурси; ознайомленню 3 культурними набутками рідного народу; вихованню патріотизму i моральних переконань; розвитку потреби в удосконаленні культури власного мовлення.

Мовну змістову лінію складають відомості із загального мовознавства (українська національна мова; походження мови, закономірності їі розвитку; мова як система, внутрішні підсистеми мовної системи; функції мови; мова й мовлення, мова та мислення; структура мови; джерела української літературної мови; мова як суспільне явище; писемна й усна форми літературної мови; колоритно-стильові різновиди мовлення, спілкування, ситуація спілкування). 
Особливу увагу приділено в робочому зошиті формуванню орфоепічних, орфографічних і пунктуаційних навичок з одночасним удосконаленням культури усного й писемного мовлення. Наголос робиться на практичному засвоєнні мовного матеріалу. Тут широко представлені граматико-стилістичні вправи, вправи на редагування, конструювання й аналіз текстів професійного спрямування, мовні спостереження, робота з лексичними і граматичними синонімами, інші види робіт, що сприяють засвоєнню теорії мови, удосконаленню орфографічної пильності, культури усного й писемного мовлення та розвитку мовного чуття й логічного мислення майбутніх філологів.

Мовленнєво-діяльнісна змістова лінія під час вивчення профільного курсу української мови та опрацювання робочих зошитів для 10 і 11 класу передбачає збагачення словникового запасу учнів; формування мовленнєвих навичок через створення власних висловлювань; оволодіння мовно-мовленнєвими засобами відповідно до теми і ситуації спілкування; поглиблення мовних знань за рахунок інформації профільно-орієнтованого характеру.

Комунікативно-діяльнісна змістова лінія зорієнтовує на вдосконалення мовленнєвої комунікації. Володіння мовою забезпечує змогу правильно будувати висловлювання, щоб передати свою думку, що дає можливість ефективно здійснювати як професійну, так і комунікативну діяльність [2].

У процесі вивчення профільного курсу мови й опрацювання робочих зошитів учні залучаються до пошуку інформації в наукових журналах, у мережі Інтернет, у фахових підручниках, аналізують, повідомляють, висловлюють аргументи «за» i «проти», дискутують щодо мовної ситуації в Україні, шляхи розвитку мови, особливості iї функціонування, історію мови, мовознавства й інші професійно орієнтовані теми. Реалізація професійної комунікативно-діяльнісної змістової лінії в навчанні учнів профільної школи сприяє розвитку їх активності в пізнавальній діяльності, розширенню комунікативних можливостей, створенню реальних комунікативних ситуацій [3].

С. Караман слушно завважує, що зміщення акцентів із навчання насамперед граматики на оволодіння мовою в усному й писемному мовленні, спілкуванні, на розвиток зв'язного мовлення зовсім не означає, що має бути послаблена увага до граматики [5, с. 7].

Концепція пропонованого робочого зошита спрямована на поєднання роботи 3 розвитку культури мови й мовлення із засвоєнням теоретичних знань та підвищенням правописних і стилістичних умінь і навичок, поетапне формування мовно-мовленнєвих компетентностей.

Важливим компонентом у розробленні концепції також є вибір ефективних форм і технологій навчання.

У процесі вивчення профільного курсу української мови нами обрано такі форми роботи: уроки-семінари, захисти пропонованих проектів, тренінги, проведення лінгвістичних «круглих столів», дискусії, рольові ігри й ін., які сприяють удосконаленню мовно-мовленнєвих умінь i навичок, професійного спілкування на задану тему, підвищують інтерес до створення й розв'язання тестових завдань тощо.

Рекомендуємо як традиційні, так й інноваційні методи профільного навчання української мови: проблемний виклад матеріалу, спостереження над мовою, експеримент, частково-пошуковий метод, дослідницький метод, метод моделювання, інформаційно-комунікаційні технології, комунікативні тренінги $[1 ; 6 ; 7]$. 
У процесі вибору ефективних технологій профільного навчання української мови враховано мету й завдання філологічного профілю, умови системи профільної освіти. В основу навчального процесу покладено сучасні інноваційні технології навчання (інформаційно-комунікаційні, тренінгові, ігрові).

У робочому зошиті також передбачено моделювання різних професійних ситуацій, оскільки це ефективний засіб розвитку креативного мислення учнів та їхньої професійної орієнтації. Ефективними $є$ також ігрові форми навчання, що сприймаються учнями 3 великим інтересом. Цікавими для учнів $є$ дискусії на професійно-орієнтовані теми: «Мова реклами в ЗМІ», «Я - перекладач», «Психологічний вплив мовлення лектора на аудиторію», «Якби я був учителем...», «Роль мови в процесі державотворення», «Чи потрібна професія редактора?», «Які якості необхідні тележурналісту, а які - науковцю?», «Вплив мовлення політиків на політичну ситуацію в державі» тощо.

Потребу в професійно зорієнтованому спілкуванні учні реалізують під час комунікативних тренінгів. Запропоновано такі теми для проведення комунікативних тренінгів: «У чому сенс життя», «Проблеми сучасної освіти», «Що таке щастя?», «Заговори, щоб я тебе побачив (Сократ)», «Роль засобів масової інформації в житті сучасного суспільства», «Сучасний письменник», «Сучасний учитель», «Чи потрібний переклад світової літератури українською мовою?», «Як впливає мовна ситуація в країні на економічну та політичну ситуацію?», «Інтерв’ю», «Укладання угоди», «Мова сучасних письменників», «Молодіжний сленг: за і проти», «Як боротися з суржиком».

Продуктивною визнано роботу з аналізу мовної ситуації, вивчення мовлення учасників, проведенням словникової роботи з професійної термінології.

Отже, профільне вивчення української мови відповідно до розробленої концепції створює для учнів профільних класів виняткові можливості: опанувати особливості мовної системи, специфіку використання різних мовних одиниць залежно від сфери та мети вживання; виробити навички правильного користування мовними, мовленнєвими, комунікативними норм професійного спілкування; здобути уміння i сформувати навички орієнтуватися у сферах професійно орієнтованого мовлення. Вибір ефективних методів і технологій навчання, форм діяльності, способів взаємодії вчителя й учнів надає змогу оптимізувати процес профільного навчання української мови, удосконалити організацію індивідуальної, групової, колективної діяльності учнів - майбутніх філологів.

\section{Література}

1. Білясв О. М. Проблемні ситуації й пізнавальні завдання на уроках мови / О. М. Біляєв // Українська мова і література в школі. - 1974. - № 4. - С. 62-63. 2. Вятютнев М. Н. Коммуникативная направленность обучения русскому языку в зарубежных школах / М. Н. Вятютнев // Русский язык за рубежом. - 1977. - № 6. C. 38-45. 3. Загальноєвропейські рекомендації 3 мовної освіти : вивчення, викладання, оцінювання / Наук. ред. укр. видання д-р пед. наук, проф. С. Ю. Ніколаєва. - К. : Ленвіт, 2003. - 237 с. 4. Караман С. О. Методика навчання української мови в гімназії: навч. посіб. для студ. вищ. закладів освіти / Станіслав Олександрович Караман. - К. : Ленвіт, 2000. - 272 с. 5. Караман С. О. Зміст і технологія навчання української мови в гімназії : дис. ... доктора пед. наук : 13.00.02 / Станіслав Олександрович Караман. - К., 2000. - 425 с. 6. Полат Е. С. Интернет на уроках иностранного язика/ Е. С. Полат// Иностранные языки в школе. - 2001. - № 2. - С. 14-19. 7. Рожило Л. П. Метод спостереження на уроках 
мови / Л. П. Рожило, О. М. Шпортенко // Українська мова і література в школі. 1973. - № 2. - C. 58-64.

\section{ФОРМУВАННЯ КРИТИЧНОГО МИСЛЕННЯ УЧНІВ НА УРОКАХ РОСІЙСЬКОЇ МОВИ ТА ЛІТЕРАТУРИ ЯК ОСНОВА РОЗВИТКУ ІННОВАЦЙНОЇ ОСОБИСТОСТІ}

Лисевич О. В., Медведєва Н. Г. Формування критичного мислення учнів на уроках російської мови та літератури як основа розвитку інноваційної особистості.

У статті розкрито прийоми й методи формування критичного мислення учнів, обгрунтовано їх уплив на розвиток інноваційної особистості. Доведено, що необхідними умовами для вияву критичного мислення учнів $є$ наявність творчих особистостей, творчого процесу, творчого середовища.

Ключові слова: критичне мислення, нові педагогічні технології, інноваційна особистість.

Лисевич А. В., Медведева Н. Г. Формирование критического мышления учеников на уроках русского языка и литературы как основа развития инновационной личности.

В статье раскрыты приёмы и методы формирования критического мышления учащихся, обосновано их влияние на развитие инновационной личности. Доказано, что необходимыми условиями для проявления критического мышления учеников является наличие творческих личностей, творческого процесса, творческой среды.

Ключевые слова: критическое мышление, новые педагогические технологии, инновационная личность.

Lisevich A. V., Medvedeva N. G. The formation of critical thinking at the lessons of the Russion language and literature as a basis for the development of innovate personality.

The article presents the techniques and methods of formation of critical thinking. It substantiates their influence on the development of innovate personality. The author also insists that the presence of critical thinking at the lessons, creative process, and creative environment are the important factors for the realization of the pedagogical creativity in the process of teaching.

Key words: critical thinking, new teaching technologies, innovate personality.

В умовах створення демократичної держави важливе значення має виховання людей, які мислять самостійно i творчо. Людей, які б мали змогу критично осмислювати факти і події довкілля, які б втілювали нові ідеї в усі галузі суспільства, були б вільними від конформізму й догматизму, оскільки незаперечним $\epsilon$ факт, що багато людей не здатні самостійно і критично оцінювати суперечності реального життя. Критичне мислення $\epsilon$ не тільки результатом демократичного способу життя, але й чинником його формування.

«Удосконалення загальної середньої освіти спрямоване на переорієнтацію навчання на розвиток особистості учня, навчання його самостійно оволодівати новими знаннями. Сучасна молода людина об'єктивно змушена бути більш 